\title{
Bir Anadolu Seyirlik Oyunu (Pıngıdık) ve Ritüelin Çözümlenmesi
}

\author{
An Anatolian Ritual Game 'Pingidik' and Content Analysis
}

\begin{abstract}
Okay SÜTÇÜOĞLU*
Öz: Pıngıdık Antalya/Finike/Gökbük Köyü’nde halen oynanmakta olan bir Anadolu seyirlik oyun türüdür. Saya Gezmesi, Arap Oyunu, Kış Yarısı, Cemal Oyunu ve Berabona gibi çok sayıda seyirlik oyun versiyonuna kısmi benzerliklerinin ötesinde çok daha derli toplu, sembolik olarak daha fazla içeriğe sahip ve tek bir Tahtacı köyünde rafine olarak kalabilmiş olmasından dolayı oldukça özel bir yere sahip olacak değerdedir. Oyunun içeriği ve mesajları tahlil edildiğinde sadece bir seyirlik oyun olmadığı aynı zamanda doğrudan bir 'erginlenme ritüeli' olarak tanımlanması gerektiği anlaşılmaktadır. Sembol ve figürlerin gerek Klasik Mitoloji gerekse Asya Türk gelenekleri ile bağlantılar kurulabilecek veriler sunması bir tartışmayı da beraberinde getirecek gibidir. Bu açıdan oyunu tanıtmak üzere, kendi içinde bölümleyip figür ve sembolleri ayrıştırarak, gerek Klasik Mitoloji gerekse Türk gelenekleri içindeki göndermelerine mukayeseli bir bakış sunmak araştırmanın omurgasını oluşturacaktır. Araştırmanın sonunda animistik öykünmeler, sembolik objeler, oyun grupları, hiyerarşik iş bölümleri, çatışma ortamı, saygı ve onama gibi birçok unsur teker teker anlamlandırılıp kökenine dair görüşler netleştirilmek üzere bilimsel bir tanım ve önermeye ulaşılması amaçlanmaktadır.
\end{abstract}

Anahtar sözcükler: Pıngıdık, Tahtacı, Seyirlik Oyun, Erginlenme Ritüeli, Fallus Tapınımı

Abstract: 'Pıngıdık' Antalya/Finike/Gökbük is a type of game still being played in an Anatolian Folk Village. Beyond the partial similarities, when compared with many theatrical game versions like Saya, Arab, Winter Semi, Cemal Games and Berabona, because it is much more tidy, has symbolically more content and remains and survives as refined in a single Tahtacı village, it is worthy of a rather special place. When the game's content and its messages are resolved, we can see that it ends in a way that indicated it is not only a theatrical game but also directly a rite of passage. When the rich symbols and figures are treated separately, the fact that it presents data which may be linked to both classical mythology and Asian Turkish tradition is likely to cause discussion. In this respect, in order to introduce the game, providing the references of both classical mythology and Turkish traditions with a comparative overview by classifying the game itself and isolating the figures and symbols will form the care of this research. Because, discussions over the opinions presented to this kind of game still has not ceased. At the end of the research, this study aim that many factors such as animistic emulations, symbolic objects, game groups, hierarchical divisions of labor, conflict environment, respect and approbation will be explained individually and reach a scientific definition and clarify its origin.

Keywords: Pingidik, Tahtac1, Folk Games, Initiation Ritual, Phallus Cult

\footnotetext{
* Dr, Selçuk Üniversitesi, Edebiyat Fakültesi, Arkeoloji Bölümü, Konya, okaysutcuoglu@hotmail.com
} 


\section{Giriş}

Anadolu köylerinde halen oynanmakta olan animistik tasarımlı birçok seyirlik oyun arasında, icra edildikleri bölgelerin birbirlerine uzaklıklarının doğası gereği kısmi farklılıklar olmasına rağmen, müşterek bir kökü işaret eden pek çok ortak yan bulunmaktadır. Bu oyunların müşterek yanları, farklı disiplinler tarafından farklı köklere uzatılmaktadır. Bu konuda ortaya konulmuş 3 görüş tanımlanabilir; ilki, bu oyunların Klasik Mitoloji, dolayısı ile Hellen medeniyeti ve etkinliklerinden kaynaklandığıdır. Diğgeri, Orta Asya Türk geleneklerinden ve özellikle şamanist İnançlar'dan oluştuğu, sonuncusu ise Türklerin göçlerle geldiği Anadolu'da eski geleneklerini yeni karşılaştıkları kültürlerle harmanladıklarıdır. Pıngıdık (Fig. 1) oyunu bu çerçevede ele alınması gereken oyunlardan birisi olup, ötekilere göre daha derli toplu, aşamaları, figürleri ve eylemleri daha iyi tanımlanabilir netliktedir.

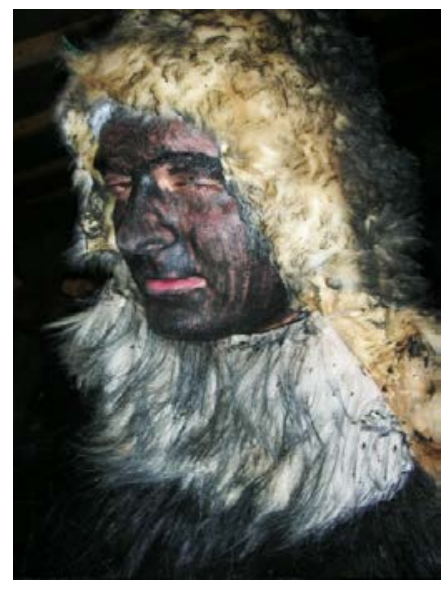

Fig. 1. Pıngıdığın portresi.

Gökbük Köyü yerleşik halkının tamamı Tahtacı Türkmenlerden oluşmakta ve köye yerleşim tarihleri 1850 yıllarına inmektedir. Yaşlı insanların beyanlarından ilk sıralar Rum olarak bilinen yerli Hıristiyanlarla bir müddet yaşadıkları, mübadele ile onların ayrılmasından sonra köyün ahalisi oldukları anlaşılmaktadır. Tahtacıların bu köye gelişlerinde geriye dönük olarak Antalya/ Kumluca İlçesi'ne kadar iz sürülebilmekte, daha önceki yerleri hakkında bilgi bulunmamaktadır; ancak Adana'dan Çanakkale'ye kadar uzanan kıyı bölgelerinin dağlık kesimlerinde yer alan Tahtacı Toplulukları'nın geçmişleri ile müşterek bir tarihi seyri paylaşırlar. Konumuzu oluşturan Pıngıdık Oyunu'nun geldikleri yerlerden mi getirildiği yoksa köyün eski yerleşiklerinden mi öğrendikleri net olmamakla birlikte, yaşlı insanların atalarından öğrendikleri ve aktardıkları bilgiler doğrultusunda kendilerine özgün bir oyun olduğu değerlendirilmektedir. Pıngıdık, eskiden

21 Mart (Nevruz) da (ki halk bu döneme yayla göçü zamanı da demektedir) oynanan bir oyunken, son yıllarda ana nüfusun dışarıda olması ve bu nüfusun yarıyıl tatilinde çoğunlukla köye geçici dönüşü nedeni ile Şubat'ın ortasına denk düşen hafta sonu oynanmaya başlanarak net bir tarih şekline büründürülmüştür. Oyunun orijinin Nevruz'da olduğunun bilinmesi önemli bir husustur.

Gökbük Köyü’nün yer aldığı bölgede başka Tahtacı köyleri de vardır; ancak bu oyun, gerek Tahtacı köyleri gerekse Sünni köyler arasında sadece Gökbük Köyü’nde görünüyor olması ile çok özeldir.

\section{Pingıdık Oyununun Tasviri}

Oyuna katılanlar (seyirci halk göz ardı edilmek koşulu ile) 3 ana grup oluşturmaktadır. İlk grup ergenlik çağına gelmiş (12-16 yaş arası) erkeklerden, 2. grup orta yaş evlilerden (20-40 yaş arası), 3. grup ise ergenlik çağına gelmiş genç kızlardan oluşur.

Oyunun hazırlık aşaması ikindiden sonra başlayarak akşam hava karardığında tamamlanmış olur ve kendi içinde süreçleri vardır. Bu kısım 'hazırlık aşaması' olarak ele alınacaktır.

Pıngıdığın oyun olarak sergilenmesi ve meydanda tüm halkın katılımı ile gerçekleşen eğlence kısmı havanın kararmasından gece yarısına kadar sürmektedir ve bu kısım 'oyun kısmı' olarak ele alınacaktır.

Oyunun sonlanmasından sonra sürdürülen bazı uygulamalar ise 'son kısım' olarak işlenecektir. 


\subsection{Hazırlık Aşaması}

Ergenlik çağına gelmiş erkekler akşama doğru kendiliğinden toplanarak kendi aralarında iş bölümünü yaparlar. Bu kendiliğinden toplanma eylemi, toplumda kanıksanmış ve temeli nesiller öncesine uzanan bir kalıp olması açısından önem arz etmektedir. Her yıl gerçekleştirilen bu oyunda, yaşları gereği sırası gelen ergenleşme aşamasındaki gençler, tarif edilmeksizin sıranın kendilerinde olduğunu bilerek organize olurlar. Hatta iş bölümü aşamasında araya katılmaya çalışan ve yaşları ergenleşmiş olanlar (örneğin 18-20 yaş gibi) şiddetle reddedilerek gruptan uzaklaştırılırlar. Özellikle ritüelin merkezinde yer alan Pıngıdık figürünün hazırlık aşamasında asla bir yetişkin yer alamayacağı gibi, onların bilgi ve gözlerinden uzak bir nokta tercih edilir.

İş bölümü oluşturan grup, oyunun gerçekleştirileceği meydanın hazırlanması, bu meydanda yakılacak ateşler için odunların toplanması ve sevk edilmesi, evlerden erzak toplanmak üzere gereksinim duyulan çuval ve kapların tedariki, Pıngıdığın giydirilmesi için kullanılacak keçi derisinin temini, Pıngıdığın kim olacağı, Pıngıdığı giydirecekler ve bu grupların kimlerden oluşacağına dair kararlar verir.

Eskiden gerçekleştirilen oyunlarda yakılacak odunlar da Pıngıdığın evleri dolaşması esnasında toplanırken, son zamanlarda akşam olmadan topluca bir yerden alınarak meydana taşınmaktadır (Fig. 2).

Toplanan odunlarla meydanda ateş yerleri hazırlanır. Merkezde ötekilere göre daha büyük bir yığıı oluşturulur. Belli aralıklarla yerleştirilen diğer ateş yerlerinin üzerine ekmek pişirilecek saclar kurulur (Fig. 3).

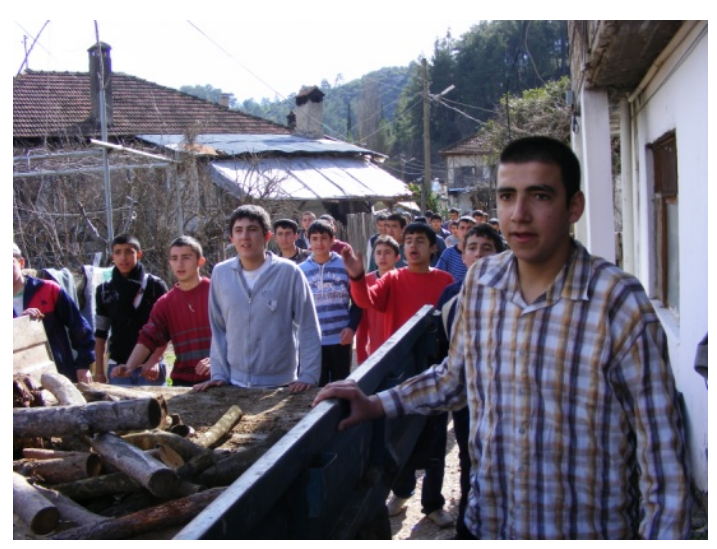

Fig. 2. Odun toplayan gençler.

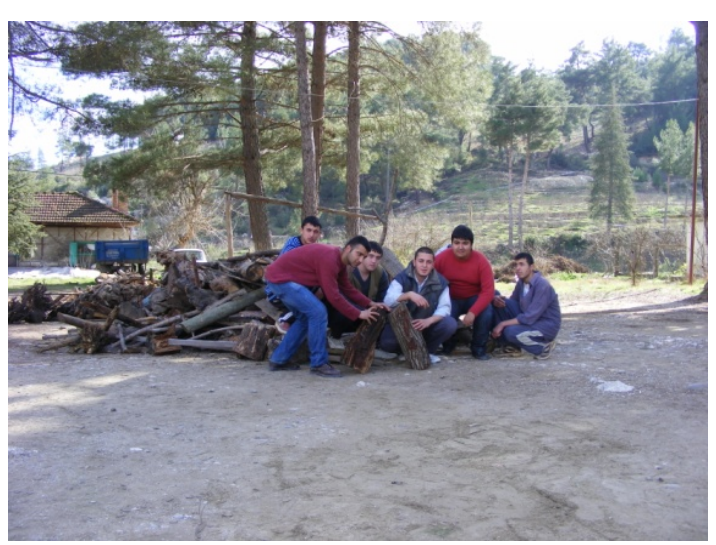

Fig. 3. Ateş yerlerinin hazırlanması.

Asıl faaliyet Pıngıdığın hazırlanma sürecidir; figür için temin edilen deri, yüz boyama için kömür, ip, sopa ve çanlar alınarak el fenerleri ile (eskiden meşale gibi kullanılan çıralarla yapılırmış) köy halkından hiç kimsenin bilmediği ve gizli olarak tutulan bir mekâna gidilir. Burası genel olarak köy dışında kullanılmayan bir mekân olabildiği gibi bir kuytu da olabilmektedir. İçeriye kimsenin girmemesi için kapıda gözetlemecilerin de bulundurulduğu bu yerde, Pıngıdık olacak kişinin elbiselerinin üzerine koyu renkli keçi veya koyun postu sıkıca sarılarak, aynı posttan tamamlayıcı bir başlık ve sakal yapılıp başa takılır. Korkutucu bir görünüm vermek üzere yüz kömür veya is ile boyanır. Pıngıdığın üstündeki deri kısmının altına omuz hizasından ve sırttan bir sopa yerleştirilerek, omuzlardan dışarı taşan bir görünüm elde edilir. Bu sopanın uçlarına da çan takılır. Bacak arasına ortalama $50 \mathrm{~cm}$. uzunluğunda bir sopa sıkıca tutturulur ve ucuna çan asılır. Pıngıdık bu sopayı elleri ile kavrar. İnsanları korkutup kaçırırken gerek bir fallus olarak gerekse binilmiş bir at olarak algı uyandırır (Fig. 4, 5, 6) Pıngıdık rolünü alan kişinin isminin gizli tutulması esastır. 


\subsection{Oyun Kismı}
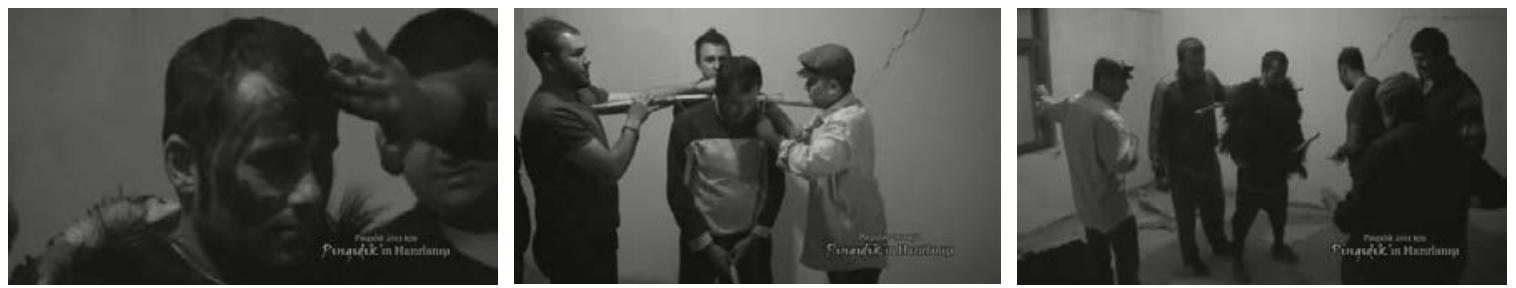

Fig. 4-5-6. Pıngıdı̆̆ın gizli bir mekânda hazırlanışı.

Hazırlanan Pıngıdığın arkasına geçen grup ellerinde teneke veya deflerle gürültüler çıkararak köye girerler. Son yıllarda orijinine uygun şekilde, köyün elektrikleri kapatılarak ellerde meşaleler taşınarak sokaklar dolaşılmaktadır. Pıngıdığa eşlik eden diğer erginlenme adayları Pıngıdığı kâh ürkütürler, kâh coştururlar, kâh ise kaçışırlar. Bir taraftan da ayinsel sesler çıkartırlar. Son yıllarda hep birden 'Osman- Osman' diye bağırarak Pıngıdığın arkasından koşmak adet olmuşsa da bunun oyunun orijininde olmadığ husustur. Sonradan uydurulan bu söylemin temeli doğrudan 4 Halife Dönemi'ndeki hizipleşmeye ve Ali'nin haksızlığa uğradığı inancına uzanır.

Pıngıdık sokak aralarında transa geçmiş bir varlık gibi önüne geleni kovalamaya, bazen durarak kendi kendine esrik hareketler yapmaya, eğilip kalkmaya, silkelenmeye, çanlarını öttürüp fallus'unu sallamaya başlar (Fig. 7).

$\mathrm{Bu}$ hareketleri yaparak grupla birlikte evlerin diş

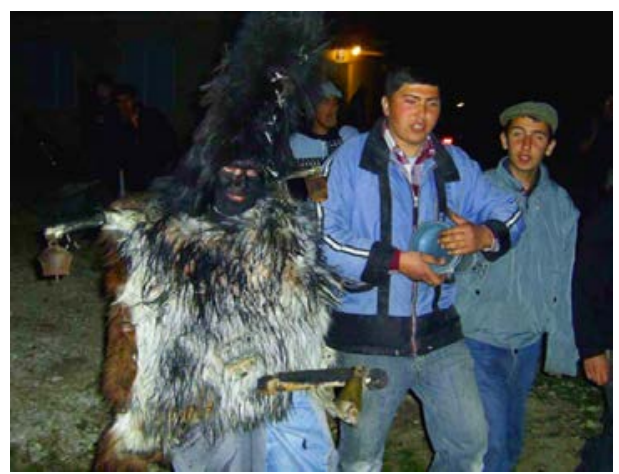

Fig. 7. Pıngıdığın sokaklarda dolaşması. kapılarına dayanır. Halk bu esnada sokaklardan evlere girmiştir ve merakla Pıngıdığı beklemektedir (Fig. 8). Her evin kapısında Pıngıdık esrime hareketlerini yapar ve sakinleşir. Bu esnada gruptan malzeme toplayıcılardan biri ev halkına hitaben 'artsın eksilmesin, taşsın dökülmesin' diyerek kaplarını uzatır. Evden bir yetişkin elinde olan un, tuz, maya, çörek otu gibi ekmek yapımında kullanılacak malzemelerden kaplara yeterince koyar (Fig. 8).

Grup hep birden 'bereket versin' diye bağırarak diğer evlere yönelir. Bu rutin tüm sokaklar ve evler dolaşılıncaya kadar sürer. Evlere çekilen halk Pıngıdığın uzaklaştığını görünce evlerinden ayrilıp meydana giderler.

Ekmek pişirilen saclarının etrafina erginlenme yaşına gelmiş genç kızlar yerleşir. Halkın katılım miktarına ve meydanın kalabalıklığına göre, 4 veya 5 yerde ekmek pişirilir. Kızlar, kendileri için hazırlanmış olan leğende getirilen malzemeler ile hamurlarını yoğururlar (Fig. 9). Kızların etrafı 4-5 kişilik erginlenme adayı erkek tarafından çevrilidir ve onlar erkekler tarafından korunmaktadır. Hamurlar mayalanıncaya kadar geçen süre içinde halk başta merkez ateş olmak üzere ateşlerin etrafinda 1sınmayı ve sohbet etmeyi sürdürürler ancak gözleri ekmeğin pişmeye başlamasinı da kollamaktadır.

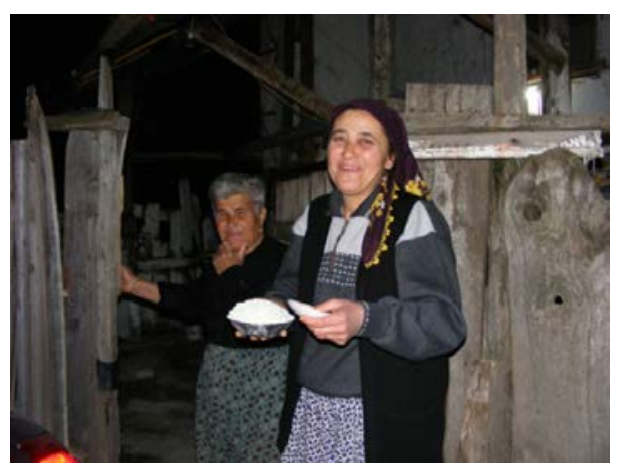

Fig. 8. Evlerinde un ve öteki malzemeler vermek üzere Pıngıdığı bekleyen hane bireyleri.

Ateşlerin etrafını halka olarak çevirmiş olan halk, kendi aralarındaki ısınma bahanesi ile ateşlere yaklaşarak sıkılaşmaya başlar (Fig. 10). 


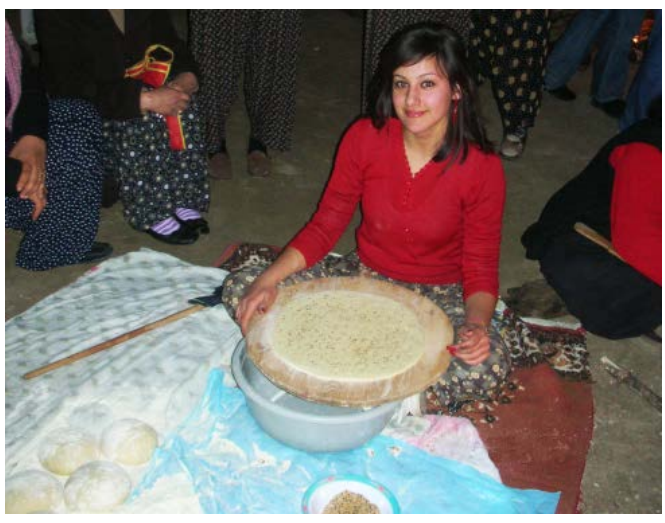

Fig. 9. Ekmek pişiren genç kızlar.

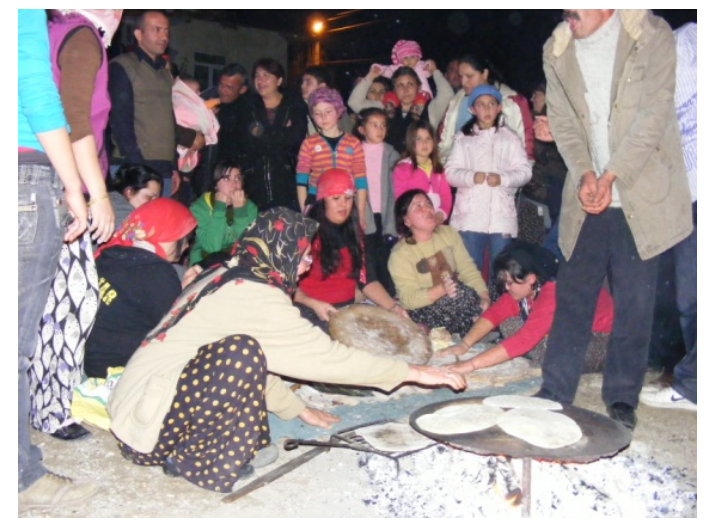

Fig. 10. Isınma rolü yaparak ateşe yaklaşan bir yetişkin.

$\mathrm{Bu}$ esasında pişen ekmeği yakalanmadan kapmak için geliştirilen bir stratejidir ve oyun kurucuları yetişkin erkeklerden oluşur. Bu hareketlenme ekmek pişiren kızların etrafında kümelenmiş genç erkekler tarafından anbean kontrol edilmektedir. Onlar için sacda pişen veya yerde yığılan ekmeği kollamak onur meselesidir. Yetişkinlerin ekmeği kapmaya, gençlerin de kaptırmamaya çalışması esasen bir meydan okumadır. Kurala göre yetişkin bir erkek, gizlice veya beklenmedik bir yerden ekmeği kaptığı anda ateşlerin ve halkın içinden yakalanmadan kaçmak zorundadır, eğer gençler tarafindan yakalanırsa ateşe atılma riskiyle karşı karşıya kalacaktır. Yakalandığı zaman ateşe atılmamak için en yakınındaki yetişkin bir kadına tutunarak onu da kendisi ile birlikte sürükler, böylece onun ateşe atılmayacağını ve kendisinin de kurtulacağını umar. Ekmek çalarken yakalanan yetişkinlerin ateşe atıldığı pek görülmez, sadece ateşe yaklaştırılıp uzaklaştırılır-

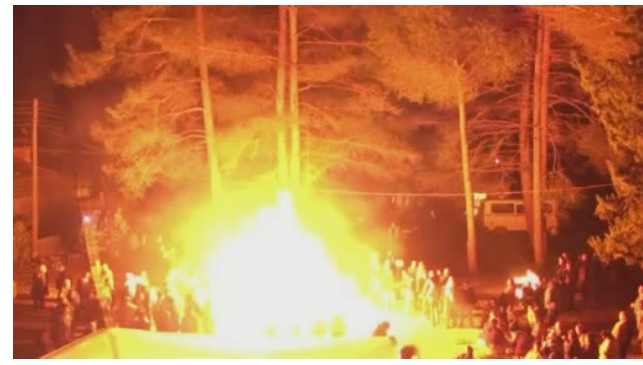

Fig. 11. Meydanda kalan gençler ve merkezi ateş. lar ancak eskiden ateşe atılıp elbiseleri tutuşanlar olduğu da bilinmektedir. Ekmek çalma görevi sadece yetişkin erkeklerde olup kadınlar buna katılmazlar. Çalma esnasında ekmek pişiren kızlar pasif durumda olup çalana müdahale etmezler, bu görev doğrudan genç erkeklerin sorumluluğundadır.

Pişirilen ekmekler genç erkekler tarafindan sacdan alınarak yerdeki bezlerin üzerine konulur. Yere konulmuş ekmekler yetişkinlerin hedefi değildir.

Tüm hamurlar tükenip ekmek haline geldiğinde doğal olarak oyun bitmiş sayılır.

\subsection{Son Kisım}

Meydanda pişirilen ekmekler gençler tarafından bir araya toplanır. Bu aşamada yaşlı ve yetişkinler meydandan ayrılmaya başlarlar. Gençler bir müddet daha meydanda kalıp eğlenmeyi sürdürürler. Aralarında etkinliğe dair yapılanlar ve genelde başarı ile başarısızlıkların kritiği yapılmaktadır (Fig. 11).

Gece yarısına doğru genç erkekler bir grup olarak ekmekleri evlere dağıtmaya başlarlar. Gelinen evin kapısı çalınır, evden bir yetişkin kapıyı açar. Bu aşamanın başından sonuna herhangi bir kimsenin fisıltıyla dahi olsa konuşması yasaktır. Elinde ekmek tutan genç önce evin kap1 eşiğine niyaz eder, eşiği 3 kez öperek ekmekle birlikte eve girer, ekmeği bir sofraya veya ocaklığa bırakarak geri geri kapıya yönelir, tekrar eşiğe niyaz ederek evden diğerleriyle birlikte ayrılır. Tüm evlere sayı olarak ekmekler pay edilmiş durumdadır. Yetersiz olduğu durumlarda 
ekmeğin bölündüğü de görülür, kural her eve bir parça ekmeği ulaştırabilmektir. Etkinlik için toplanan, odun, un ve fazla ekmeklerden bir kısmı, durumu iyi olmayan bir aileye gizlice evine konmak sureti ile verilir. Fazlalıkların kime verildiği söylenmez ve sorulmaz. Bu açıdan, Pıngıdık aynı zamanda toplumsal birlik beraberliğin ve dayanışmanın da sembolize edildiği bir ritüeldir.

\section{Pıngıdıkta Ele Alınması Gereken Sembollerin İncelenmesi}

\subsection{Oyunun Zamanlaması ve Mevsim Döngüsü;}

M. And, seyirlik oyunları tasnif ederken 'ölüp dirilme ile ilgili olanları', 'hayvan benzetmecelileri', 'yılbaşı ve yılsonu ile ilgili olanları' ayrı gruplar olarak gösterir (And, 1974, 196-256). Döngü noktası olarak kabul gören yılbaşı, değişik kültürlerde farklı iklim ve aylara denk düşebilmektedir.

Babil'de, Misır'da, Hitit'te, dramatik bir senaryo dâhilinde, iki grup oyuncu arasında yeni yıla ilişkin bir kavga sahnelenerek yaratılışın yeniden güncellenmesi ayinlerine rastlanırdı (Eliade, 1991, 57). Evrenin yaratılışının yıllık olarak tekrarlanmasıyla zaman yeniden dirilmekte, insanlar bu yenilenmeye totemik ayinler olarak katılarak eski ile yeniyi güncellemeye çabalamaktadır (Eliade, 1991, 60-64).

Yeni yıl yaratılışın ilk günüyle çakışmaktadır. Her yeni yılda evrenin yaratılışı taklit edilmekte, dünya yeniden yaratılmakta ve bunu yaparken aynı zamanda 'yaratılmakta' ve 'yeniden başlanılarak' diriltilmektedir. Günümüzde de süren yeni yıla giriş etkinlikleri bir bayram havasına büründürülürken, bayrama katılanlar tanrıların ve yarı tanrıların çağdaşları haline gelmektedirler (Eliade, 1991, 85).

Günümüzde kış ortasında oynanan Pıngıdık Oyunu'nun bazı benzerlerinin de kış ortasında oynanıyor olması ile mevsimsel olarak bağlantı kurulamaz. Örneğin böyle bir oyun 'Kış Yarısı' adı altında Erzurum'da ve hatta değişik varyasyonları Doğu Anadolu'nun birçok yerinde görülmektedir (Düzgün, 1994). Pıngıdığın zamanlamasının kışa denk gelmesinin asli sebebinin göç hareketleri ve ekonomi ile ilgili olduğu daha önce belirtilmişti.

Pıngıdık oyununu kayda almaya çalışan yerel ve ulusal medya çalışanları, oyunun yağmur duası için yapıldığını halktan birilerine söyletmeye çabalayarak orijinini bozmaktadırlar. Oysa ne Şubat'ta ne de Mart’ta Yağmur Duası'na gereksinim olmayacağı açıktır.

Konuyla ilgili literatür genel olarak Dionysos Şenlikleri ile Anadolu Köy Seyirlik Oyunları arasında bir bağ kurmaya çabalamaktadır. Klasik Tiyatro Tarihi için tutarlı olan bu görüşün bizdeki oyunlara köken olabileceği tartışılmalıdır. Bu görüş en azından Pıngıdık Oyunu için yanlıştır. Örneğin Dionysos Şenlikleri’nden baharda kutlanan Anthesteria Şenliği'nin biçemi ve kahramanları incelendiğinde, karşımıza çıkan yarışmalar, korolar, saçılar, içki tüketimi, gayri ahlaki birleşme ve trans halleri (Özdemir, 2000, 29) bizim toplumsal geleneklerimize göre benzerlikten ziyade tezatlıklar oluşturmaktadır. Dionysos Şenlikleri'nin bereket beklentisinin üzüm bağlarına ve dolayısıyla ürün olarak şaraba dönük olmasının, Türklerin içkisi olan kımızla açıklanamayacağı ortadadır. Türklerin bereket beklentisi sürüler ve çayırlarla ilgilidir. Nevruz'un yeni yılın başlangıcı olduğu inancıyla birçok farklı Türk toplumunda bayram havasında kutlandığı, değişik tören ve yarışmaların da bu bayrama eşlik ettiği, bu şenliklerde merkezi bir ateş etrafinda toplumun bir araya geldiği, kurban kesilip pay edildiği, dileklerin dilendiği bilinmektedir. Örneğin Yakut Türkleri'nce Nevruz'da toplumun bir meydanda toplanması ve söndürülmeyen bir ateş etrafında genç kız ve oğlanların dileklerde bulunması adedi vardır (Çoruhlu, 2010, 198-201). Ancak bu tarz bayram ve şenliklerde Türk aile yapısına uymayan mitolojik kökenli şenlik unsurlarına rastlanmaz. 
Anadolu Seyirlik Oyunları'nın birçok varyantının Orta Asya'da da hala var olması ve bir rota dâhilinde bunların birbirleriyle bağlantılı olduğu, Klasik Mitoloji sözü edilen inançların ve sembollerin antikçağda Orta Asya'nın içlerine kadar uzanamayacağı ortadadır. Orta Asya'dan beri dizilim dâhilinde Balkanlar'a kadar giden bu oyunlar, Türkmen Kültürü'nün var olduğu alanlarda görülmektedir. Eğer Dionysos'çulukla ilintili olsaydı, topografik olarak antikçăg yerleşimlerinin etrafinda görülüyor olmaları beklenirdi. Bu realitelere rağmen oyunlarımızla Klasik Hellen Mitolojisi arasında bağ kurmaya çabalamak, batı sentezli yaklaşımlara alıştırılmamız ve birazcık da olsa onları refere etme zorunluluğu duymamızdan kaynaklanmaktadır.

\subsection{Animistik Öykünme;}

Pıngıdık oyununda kullanılan karakeçi veya bulunamadığı durumlarda hiç olmazsa alaca keçi postuna bürünme ve yüz boyama, bizi keçiye öykünülme üzerine düşünmeye zorlamaktadır; Birçok seyirlik oyunda da görülen bu animistik taklit, araştırmacıları Klasik Mitoloji'deki benzerlerini incelemeye yöneltmiştir. Esasen keçi mi yoksa at mı olduğu dahi tartışmalı olan ve Klasik Mitoloji’de görülen figürler şunlardır;

Satyr'ler; Satyr'ler, Dionysos alaylarında yer alan doğa ruhları ve gövdelerinin belden üstü insan, belden aşağısı ise at ya da teke biçiminde olan, yarı insan yarı hayvan varlıklardır (Peterich, 1946, 46).

Pan; Bir adı da 'keçi ayaklı' olan Pan, Satyr'lerden öne çıkmış bir figürdür. Satyr'ler gibi olur olmaz yerlerde insanları korkutmasından dolayı 'panik' ibaresi ondan türemiştir (Erhat, 2003, 235). Pan adı ile Pıngıdıktaki 'pın' başlangıcı arasında ilgi kurulabilmesi önerilebilir ancak olası değildir. Oyunu sergileyen halk, teneke sesi gibi toplumu rahatsı edici gürültüleri 'tangıdu- tungudu, pangıdı- pungudu yapıyor' gibi söylemekte olduğundan, oyun adını buradan türetmiş olmalıdırlar.

Faunus; Pan'ın Roma'da anıldığı addır; ancak Faunus Satyr'lerin yetişkin olmasının aksine daha genç düşünülür (Crow, 2002, 137).

$\mathrm{Bu}$ mitolojik figürlerin konumuz açısından ortak özellikleri; keçi veya atı andırır uzuvları, Dionysos alaylarında figüratif olarak yer almaları, insanları korkutmaları ve kalkık erkeklik organları ile bereketi sembolize ediyor oldukları görüşüdür. Pıngıdığı da dâhil edeceğimiz Anadolu Seyirlik Oyunları'nda rastlanan bu tarz animistik tasarımların, yukarıda gösterdiğimiz Klasik Hellen Mitolojisi'ndeki varlıklara benzetilmesi ve oyunların topluca Satirik Oyunlar'a benzetilmesi için, bu tasarımların Türk Kültürü’nün orijininde görülmüyor olması lazım gelir. Oysa teke figürünün Orta Asya Türkleri’nde çok değişik oyunlarda ve şenliklerde görülüyor olması, orijinini nerede arayacağımızı dair somut bir işarettir. Karaçay-Malkar Kültürü'nde oynanan 'Gollu Toy' geleneği ve 'İmece Oyunu'nu' tasvir eden araştırmalar (Örneğin; Tavkul, 2012, Karça, 1954), toplumsal birliktelik, gençlerin teke görünümüne bürünmesi ve takip eden eğlence seremonisi yönünden ilgi kurulacak yerleri daha net betimlemektedir.

\subsection{Fallus ve Çanlar;}

Mitolojik varlıklarda görülen fallus'ların bu irrite edici yapıları ile topyekûn bereketi temsil ettiklerini düşünmek yanıltıcı olur. Fallus'un bereket sembolü olduğunu düşünenler olduğu gibi (Cömert, 1999, 43), bir bereket figürü olarak değil daha çok, bir büyü ve kötü ruhları uzaklaştırma üzerine kurulu olduğunu düşünenler de vardır (Tuna, 2000, 101).

Konuyu tartışmadan önce, bilinmesi gereken ve doğrudan fallus'u ile özdeşleşmiş olan Priapos'u da ifade etmeliyiz; Klasik Mitoloji'de Priapos, kendisi boyutundaki fallus'u ile üzüm bağlarını kem gözlerden korur ve bitkisel bereketi de temsil eder (Erhat, 2003, 254). İsmi de 
'gürültülü' anlamına gelen 'briapnos' kelimesinden türemiştir (Dökü, 2000, 31) (Fig. 12).

Bunlardaki fallus'un bereketle ilişkisi mitolojiden ziyade Psikanalizm kuramı ile açıklanmalıdır. Tragedya, komedya ve şamanist etkinliklerde benzer animistik öykünmeler görülür. Pıngıdığa takılan abartılı fallus'u temsil eden sopanın, erginlenme adayı gençlerin statüsüne uygun bir espri anlayışıyla, cinsel organlarının gösterimi üzerine geliştirildiğini düşünmemiz daha doğru olacaktır. Sürünün dölleyicisi olan teke görünümüne bürünme de bunu destekler niteliktedir.

Dionysos ayinlerinde görülmesinden bahisle, Anadolu Seyirlik Oyunları'nın Dionysos'çuluğa bağlanması gerektiği düşüncesi için payanda kabul edilen, 'fallus taşıma ve hayvan görünümüne

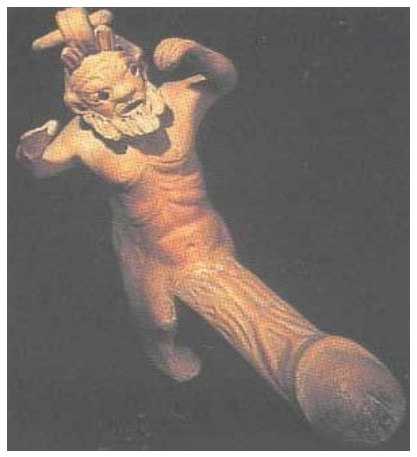

Fig. 12. Mitolojik Priapos. bürünme' eylemleri esasen arkaik uygulamalar olup, Dionysos'çuluktan çok daha eskilere uzanan ve dünyanın birçok yerinde görülebilen ritüel parçalarıdır (Eliade, 2003, 184).

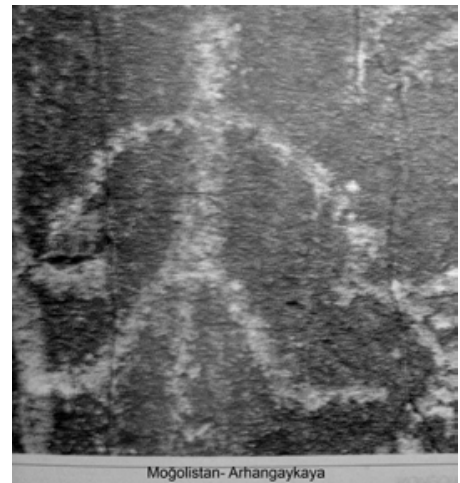

Fig. 13. Moğolistan'da fallus'lu erkek kaya damgası.

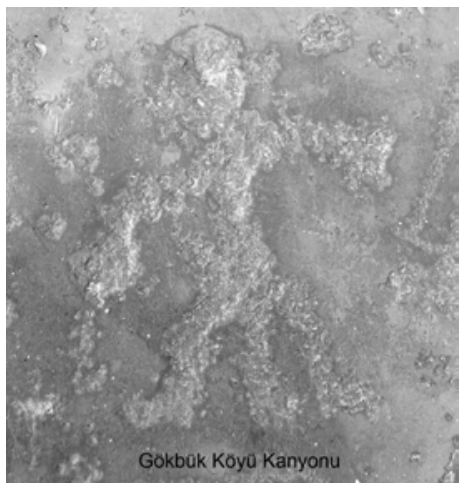

Fig. 14. Gökbük’te fallus’lu erkek damgası.

$\mathrm{Bu}$ başlık altında göstereceğimiz en temiz kanıt ise Türkler'de mevcut olan fallus inancıdır; konunun tartışmaya açık yönleri için örneklenen, Klasik Mitoloji'de görülen ve oyunun kahramanına benzeyen mitolojik yaratıkların fallus tasviri, Orta Asya Türk Kültürü'nde ve damgalarında da karşımıza çıkmaktadır. Başta Moğolistan Bölgesi olmak üzere, tüm Orta Asya kayalıklarında (Res. 13) yaygın şekilde görülen fallus'lu erkek damgası (Somuncuoğlu, 2008, 57) birebir aynı şekilde Gökbük Köyü Kanyonu'nun kayalarında da mevcuttur (Fig. 14).

Sahada rastlanan damgaların Tahtacılar tarafından yapılıp yapılmadığı önem arz etmez; çünkü Tahtacılar ve etraf köylerin yerleşikleri topyekün Göçebe Türkmen Kültürü’nü taşıyan unsurlardır.

Pıngıdık fallus'una takılan çanların benzerleri, iri ziller ve defler olarak Kybele şenliklerinde çılgınca dans ederek kendilerinden geçenlerde karşımıza çıkmakla birlikte (Wilkinson, 2011, 84) sebeplerini Klasik Mitoloji'de aramak yersizdir. Dionysos ayinlerindeki teke öykünmelerine, dolayısı ile çanları bu manaya bağlama görüşlerinden ziyade, göçebe ve hayvancılıkla uğraşan Türk Kültürü'nde aramak daha doğru olacaktır.

\section{4. Çatışma, Ateşe Atma, Ölme Dirilme;}

Frazer (Frazer, 1992, 308); bir Suriye miti olan Aphrodite ve Adonis, bir Misır miti olan İsis ve Osiris, bir Frigya miti olan Kybele ve Attis mitlerinde ölme ve dirilme motiflerinin ortaklıklarından dolayı, bunların yaz ve kış çatışmasını da içinde barındıran, doğanın ölüp dirilmesi, bitkinin ölümü, parçalanması ve toprağa tohum olarak düşüp yeniden dirilmesi ile ilişkili 
olduğunu söyleyerek, dünyanın birçok yerinde bu tarz ritüellerin görüldüğünden söz etmektedir.

Thomson'a göre ilkellerde mevsim döngüsü ve buna paralel kurgulanan erginlenme ritüelleri tragedyanın kökeninde etkin rol oynamaktadır (1990, 196-198). Anadolu oyunlarında da, eskiyi, kötüyü, çirkini temsil eden güç, karşıtı olan yeniyi, güzeli, iyiyi temsil eden güç tarafından öldürülür. Şaman ayininde de ayılıp bayılma, ölüp dirilme vardır (Özhan, 1997, 296). Pıngıdık oyununda, gençlerle yetişkinler arasında cereyan eden ateşe atma eyleminin, bilindik ölüp dirilme ayinlerine benzer yanı yoktur. Konunun akışı gereği vurgulanan bu unsur ancak bir erginlenme ve meydan okuma olarak açıklanabilir.

\subsection{Oyuncuların Yaş Grubu ve Erginlenme;}

Pıngıdık oyununda yetişkinler ile erginleşmekte olanlar arasında doğrudan bir rekabet göze çarpar. Benzer şekilde, Sümer, Hitit Mitolojileri ve Klasik Mitoloji’de bir dizi Tanrı kuşağ arasında hükümranlığı ele geçirme çatışması anlatılmaktadır. Bu çatışmalarda ortak yön, hep gençlerin kazanıp yeni bir düzene geçmeleridir (Eliade, 2003, 184).

Harrison, dramanın kökenine dair düşüncesini belirtirken erginlenme ile ilişki kurarak 'kouros' sözcüğü üzerinde durur. 'Kouros' sözcügüü erginlenme aşamasında olan delikanlıları anlatır. Homeros ise şiirlerinde kouros'lardan 'kuretalar' olarak bahseder (Thomson, 1990, 112). Köyde ve daha Anadolu'nun pek çok yerinde, Pıngıdık oyununda merkezde yer alan erginlenme aşamasındaki gençler çağındaki erkeklere 'kerata-keratalar' diye seslenilmesi son derece şaşırtıcıdır. Aslında erginlenme ritüelleri atalar kültünün etkisi altındadır. Bu manada ritüelde yer alan bazı eylemlerde adayın sınanması ve çizgilerini bellemesi hedeflenir (Tuna, 2000, 49).

Küresel olarak ergenlik çağına gelen çocuklar için bir erginlenme töreni birçok yerde görülür; çocuklar bu yansılama töreni sırasında düşsel bir biçimde ölüp yeniden doğarlar ve böylece çocukluktan çıktıklarını kanıtlamış olurlar (Thomson, 1998, 57).

Erginlenenin yetişkine meydan okuması, statüsünü ortaya koyuş biçimi olarak sıranın kendisinde olduğunu göstermek adına onu yakalaması, ateşe atması ve kendine ait olanı koruması, hiç kuşkusuz sadece mitolojik figürlerle anlatılacak kadar dar bir figür olamaz. Bu ve buna benzer birçok erginlenme ritüelinin ve bunlarda görülen meydan okumaların, ilkel insana uzanan ve dişilerin bölüşümüne dair bir psikolojik altyapısı vardır. Bu psikolojik altyapının, kendiliğinden farklı coğrafyalarda yeşeren uygarlıklarda benzer mitleri doğurması, insan türünün gelişimine paralel beklenen bir olgudur. Freud'a göre, erginlenenlerle yetişkinler arasındaki gizli husumet, kadınların paylaşımı, yönetimi ele geçirme, lider olma ve idareci olma dürtüleri insanlığın şimdiki konumunun temel nedenleridirler $(2002,15)$.

Erginlenme aşamasının ve adayın kendini göstermesi eylemlerini Türk geleneklerinde de görmekteyiz; çocukların temel binicilik eğitimini koyuna bindirilerek yapmaları, rüştünü ispat için erginlenenlerin kendilerini kanttlamaları, Dede Korkutça rüştünü ispat edenin adlandırılması gibi hususlar, ritüelin sadece Klasik Mitoloji’ye göndermede bulunmadığını söylememiz için yeterlidir. Dede Korkut'un Boğaç Han hikâyesinde; 'oğlançuğını dayalara virdi saklattı. At ayağı külüg ozan dili çevük olur. Eyegülü ulalur kapurgalu büyür. Oğlan onbiş yaşına girdi' şeklinde yaptığı girişte, esasen Oğuzlarda Alpliğini ispat etme ve kimliğini bulma yaşının 15 olduğunu, bu yaşa kadar çocuğun toplumun bir üyesi olarak kabul görmediğine dair şifreleri de vermektedir (Duymaz, 2000, 112).

Çocuk doğduğunda fiziki bir varoluşa sahiptir; henüz toplum tarafından tanınmaz ve kabul edilmez. Yeni doğana tam anlamı ile canlı statüsünü, doğumdan sonra uygulanan ayinler sağlamaktadır. Topluluğa katılma ayinleri erginlenenlerle erişkinlerinkinde farklıdır. Yeni yetmelerin 
topluluğa kabulü ayinlerine katılmaları zorunlu olmasına rağmen, erişkinlerin dâhil edileceği toplulukların ayinleri belirli kişileri kabul etme ve farklı semboller kullanma açısından ayrışır. Topluma katılma genelde üçlü bir ifşa içermektedir; kutsalın, ölümün ve cinselliğin ifşası. Çocuk tüm bu deneylerin cahilidir; katılma töreninden geçen bunları tanımakta, üstlenmekte ve yeni kişiliği ile bütünleşmektedir (Eliade, 1991, 161-165).

Alevi-Bektaşi inancında da ibadet ile özdeş olan cem törenlerine bekârlar katılamazlar. Sadece gençlerin alışması için 'koldan kopan erkânında' bekârlara yer verilir (And, 1974, 88). Tahtacılar özde Türk geleneklerinin orijinini barındıran, Alevi Bektaşi inancına sahip bir topluluktur. Kendi cemlerinde de doğal olarak bekârlar yer almamaktadır. Pıngıdık ritüelinde bir aşama olan 'Pıngıdığın gizlice hazırlandığı' mekâna ve oyunun icra edildiği meydanda yer alan ekmek pişirme yerlerine evlilerin yaklaştırılmamaları doğrudan ritüelin 'erginlenme' amacına göndermedir.

Pıngıdık oyununda erginlenme kabulü sadece erkeklerle sınırlı olmayıp, oyunda fazlaca fonksiyonu yok gibi görülse de kızları da kapsamaktadır: Kızlarda topluma katılmak için erginlenme kriteri ilk ay halidir ve bu fizyolojik belirti bir statü kopuşuna işaret etmektedir. $\mathrm{Bu}$ dönemin yaş aralığı olan 14-15 yaşları kutsallığa adım atma ve kadınlık rolünün üstlenilmesi için ayinlere alınacakların odak noktasını oluşturur (Eliade, 1991, 170). Oyundaki görevleri gereği kendileri için hazırlanmış olan düzen içinde hamuru yoğurup ve ekmek haline getirerek statülerinin yeni yetme kızlıktan artık bir ev kadını ve ana adaylığına yükseldiğini göstermektedirler. $\mathrm{Bu}$ cinsiyet rollerini oynarken, etraflarını çevirmiş olan yaşıtları erkeklerin de gölgesinde kalarak 'eski ile yeninin, kadın ile erkeğin' toplum içindeki rollerini de göstermektedirler. Oyundaki bu kahraman grubu ve ekmek pişirme eylemlerinin, mitolojik kökenli şenliklerde görülen saçılarla bağlantılı olduğu görüşünü ileri sürenler çıkabilirse de, bunun zorlama olacağı aşikârdır. Bu grubun eylemleri ve sembolleri doğrudan Türk aile yapısı içinde kadın ve genç kızların statülerinin belirginleştirilmesinden gelmektedir.

\subsection{Statünün Onanması ve Pekiştirme;}

Pıngıdık oyununun asli amacının erginlenme olduğuna, senaryo ve sembollerin de bu amaca uygun olarak tasarımlandığına dair en belirgin ipucu ritüelin son safhasında görülmektedir: Oyunun tamamlanmasından sonra yetişkinlere karşı çağdaşları olan dişileri ve üretimlerini koruma rollerini yerine getiren gençler, üretilen ekmekleri eşit bir şekilde evlere pay edip dağıtmak durumundadırlar. Bu kısım, baştan beri sürdürülen toyluk dönemine uygun pespaye ve espirili davranışlarına zıt bir şekilde olağanüstü bir ciddiyet içinde yapılan aşamadır. Bu aşamada eşiğin $3 \mathrm{kez}$ öpülerek hürmet gösterilmesi ve ortamda zaruri tutulan sessizlik irdelenmesi gereken son sembolik davranıştır. İnsanların oturdukları evlerin eşiklerine ayinsel işlevler yüklenmiştir ve bu nedenle çok sayıda ritüel evin eşiğinin aşılmasına eşlik etmektedir. Birçok toplumsal gelenekte eşiğe selam verilmekte veya tapınma hareketleri yapılmaktadır. Bu haliyle eşik kamusaldan özele, din dışından kutsala bir geçişi sembolize etmektedir (Eliade, 1991, 5-6).

İnsanların barınağı olan ev, aileyi ve mahremiyeti örten bir yapı ve 'axis mundi'nin (dünyanın merkezi-dinsel tapınak) karşılığı olan 'imago mundi' olarak ayin ve efsanelerde önemli bir rol oynamaktadır. Bu açıdan evin eşiği dışarı ile içeriyi yani din dışından kutsala geçişi somutlamaktadır. Amaca uygun olarak erişkinler topluluğuna katılma ayin ve efsanelerinde bol miktarda sembolik olarak yer almaktadır (Eliade, 1991, 156-158).

Thomson yüzyıllar boyu, erginlemeler kırsal topluluklarda yeni mevsimi açmak için yapılan evlenmelerle aynı zamanda kutlanırdı diyerek, bilinen dinsel törenlerde hala kızların ve oğlanların bir kalabalık içinde eğlendikleri bahar şenliklerinden söz ediyor (1990, 160). Açıklamasında şunları da ekliyor; 'o zaman eşler alınır. Yaşam ancak iki cinsin birleşmiş 
güçleriyle uyanabilir. Baharı, ancak bir gençlik şenliği uyandırabilir'.

Eşiğin 3 kez öpülmesi eyleminde görülen üçleme, İslam Tasavvufu'nda Mevlevilik ve Bektaşilikte sıkça karşımıza çıkmaktadır (Çoruhlu, 2010, 221). Bu ritüelde yer verilmesi uygulayıcılarının mensup oldukları inançsal normlara uygun olarak 'Allah, Muhammed, Ali' adına yapıldığı açıktır.

Konutun eşiğini aşan ve ekmekleri sunan gençlerin ve konut sahibi yetişkinlerin olağanüstü sessizliği, sanki yetişkinliğe kabulü onama ve onlara saygı niteliğindedir. Böylece artık rüştünü ispat etmiş yetişkinler olarak 'eve kazandıkları veya ürettikleri ekmeği getiren erkekler' olmuşlardır ve bu statüleri onlara boyun eğilerek, kutsala gösterilen saygıdan farksız şekilde onurlandırılmaktadır. Aynı yaş grubu takip eden aylardaki Hıdrellez gecesi, aynı şekilde evlerin kapısını çalacak ve her hane bireyine sessizlik içinde el değmemiş bir kaynaktan getirdikleri sudan içirerek statülerini pekiştireceklerdir.

\section{Sonuç ve Değerlendirme}

Oyun, akışı gereği bir dramayı değil komedyayı betimlemektedir. Tiyatro üzerine yapılan araştırmalarda tragedyanın ve komedyanın birbirleri ile ilişkili ancak farklı kesimlerde ortaya çıktığına dair bir görüş hâkimdir. Örneğin Thomson aristokrasi ve demokrasi sürecinde tragedyanın biraz daha resmi ve kentsel olduğunu, komedyanın ise köy oyunları ile şekillendiğini düşünmektedir (1990, 196-198). Başlangıçtan beri Pıngıdık ve Anadolu Köy Seyirlik Oyunları'nın hem Klasik Mitoloji'yle hem de Şamanizmle ilgisinin kurulmaya çalışılması çabasına uygun olarak, komedyanın da bir şekilde Asyatik olabileceğine dair görüş belirtmemiz sıra dışı olabileceği gibi ele alınması gereken fikirler de ortaya koyabilir. Tiyatral araştırmalar pek sözünü etmese de, komedya; doğrudan Hellence'deki 'kome (köy)' anlamından türetilmiş olmak durumundadır. Ko- kon- konak- komşu- konuk- komı- kom- köm ibareleri doğrudan Eski Türkçe'den beri kullanılan ve içeriğinde kom-köy açıklamalarını da taşıyan isimlerdir (Gülensoy, 2011, 536). Bunlar Orta Asya Türk lehçelerinde ve hatta Ermenice'de dahi müşterektirler. Bu haliyle; gerek komedyanın kom/ köy ilişkisini, gerekse bu adın kökünün de dolaylı olarak Asya'da aranabileceğini belirtmekte fayda vardır.

Pıngıdık oyununun figür ve eylemlerinin, Klasik Mitoloji'deki varlık ve eylemlere benzetilmesi mümkün olmasına rağmen, Anadolu'da ve Balkan Türkleri arasında oynanan benzer oyunlarla bağıntısı, Orta Asya Türk ve şamanist gelenekli olmasının daha makul olacağını göstermektedir.

Şamanizm'in kökeni ilkel devirlere kadar uzanır ve olasılıkla prehistorya'da sihir ve büyüye dayalı davranışların devamı niteliğindedir. Böyle köklü bir ritüelin izleri ancak ve ancak göçebe kültürüne sahip rafine topluluklarda aranmalıdır. Sosyalleşen ve yerleşik düzen ile asırlardır kültürel evrimini değiştiren toplumlar çağlar boyunca şamanist ritüellere uzanan geleneklerini dışlarken, hayvancılığa ve diğer yaşamsal kaynaklara bağlı (Tahtacılar günümüzde dahi az görülmekle birlikte orman işçiliği için göçer hayatlarını devam ettirmektedirler) göçer olarak günümüze kadar ulaşmış topluluklarda eski ritüellerin izlerine rastlama olanağımız daha fazladır.

Pıngıdık Oyunu; Orta Anadolu'da oynanan Saya Gezmesi, Doğu Beyazıt'ta oynanan Köse, Çankırı'da oynanan Bağbozumu (Tuna, 2000, 190-192; 194-198), Doğu Karadeniz'de oynanan Berabona Zamanı (Tokdemir, 1993, 187) gibi oyunlarla kısmi benzerlikler göstermektedir. Özellikle Trakya'da oynanan Cemal Ritüeli ile çok benzeşir. Cemal Ritüeli Yugoslavya'da yerleşik Türkler arasında Koledarlar, Şirovariler, Zivonari, Vukovi ve Camala adları altında, Bulgaristan'da ise Kukeri adıyla oynanır (Artun, 1983, 235-236). Balkan Türkleri arasında oynanan Cemal Ritüeli'nde de Pıngıdıkta olduğu gibi gençlerin teke postuna bürünmesi, yüz 
boyama, abartılı bir fallus ile çanlar görülmesi, ritüellerin Asyatik ve şamanist kökenli olduğunu göstermektedir. Zira Pıngıdığın ve Anadolu'da rastlanan benzer oyunların özgün kültürünü koruyabilmiş ve Heterodoks Müslümanlar arasında rastlanıyor oluşu kökte aynı yerden geldiğini açıklamaktadır. $\mathrm{Bu}$ oyunların her biri birbirlerinden bağımsız ve uzak bölgelerde oynanmakta; ancak Orta Asya Kültürü’nü özünde barındıran kitlelerde varlığını sürdürmeye devam etmektedir. Bazı araştırmacılar (ă̆ırılıklı olarak Arkeoloji ve Antropoloji disiplinlerinden) bu ritüellerin köklerini Klasik Mitoloji'de yer alan Dionysos şenliklerinde aramaktadırlar ancak unutulmamalıdır ki, bu oyunlarda sarhoşluk ve transa geçercesine dans eden ekstrem gruplara yer verilmez. (Köy halkında yerleşik bir içki kültürü vardır ve düğün, kutlama, kurban ve Pıngıdık gibi bu tarz ĕ̆lencelere eşlik eder. Bu eylem, ritüele bağlı olmadı̆̆ gibi, tahtacılar içinde içkinin abartıldiğı sosyal bir sorundan kaynaklanmaktadır. 1970 yılına kadar bu tarz etkinliklerde eğlencelere eşlik eden abartılı bir içki kullanımı görülmemektedir). Aynı şekilde Avrupalı bilim insanlarının, Balkanlar'da rastlanan Cemal Ritüeli ve türevlerinin köklerini kilise ve Bizans mimus'larında arama çabaları yeni tartışmalara neden olmaktadır (Tuna, 2000, 203). Oysa ritüellerin seyri Pagan inanç ve Hristiyanlığı değil, Orta Asya'dan Anadolu'ya ve Balkanlara doğru akan, bozulmamış Heterodoks Türk kesimlerini takip eder görünmektedir. M. And'da mimus'ların bizzat Bizans Döneminde yasak edildiğini vurgulayarak oyunların bağdaştırılamayacağını vurgulamaktadır (And, 1962, 278). Görüleceği üzere, Pıngıdık ve benzeri oyunların, eylem ve sembolik benzerliklerinin Orta Asya Türk mitolojisi ile Klasik Hellen mitolojisi arasında bir ilinti açmazı yarattığına dair ikirciklikler doğabilmektedir. Kültürlerarası etkileşim ve benzeri yönleri paylaşım hiç tartışmasız söz konusudur; ancak bu döngünün ve etkileşimin nereden nereye olduğuna dair aceleci davranıldığg ortadadır. Hellen ve Roma’yı Batı medeniyetinin merkezine yerleştiren Avrupalı bilim camiası ve bu ekolü sevinçle paylaşan içimizdeki baskın ekollerin 'konuya dair incelemeleri' sadece milli kimliği ilgilendiren branşlara (ör; tarih, edebiyat, folklor gibi) havale etmesi elimizi güçsüz kılmaktadır. Somut olarak sergilenen bu oyunların Asyatik kanıtları, yazılı ve görsel somut kanıtlarla desteklenmelidir. Bu açıdan disiplinlerarası bir işbirliği kurgulanmak durumundadır. Bunu yapan Avrupalılar, disiplinlerarası bir işbirliğine gidip, eğip bükülmeye uygun iddialar ve kanıtlar ile ritüellerin sahibi konumuna gelmektedir. Yunanistan'ın baklava, şakşuka ve lokum gibi Türk gıdalarının kendilerine ait ürünler olduğunu savlamaları örneğinde olduğu gibi, Avrupalı aydınların ve kültür politikacılarının Balkanlar'da ve Anadolu'da oynanan bu oyunların Türklere ait olamayacağ 1 düşüncesini üretmeleri kültürel fanatizmin doğası gereğidir. Türk bilim insanları ve camiasının bu konudaki özgün çalışmaları kendi disiplinleri içinden sıyrılıp öteki disiplinleri tetikleyecekken dirençle karşılaşmaktadır.

Direnç sadece alışılagelmiş yabancı hayranlığında değil, özümüzden gelen bu oyunların asırlardır gizlice oynanıyor ve rafine topluluklarda görülüyor olmasından da anlaşılabilmektedir. Asırlardır içselleştirilen ve genelleşen skolastik kültür politikaları sayesinde halk öz kültürüne sırt dönmek durumunda bırakılmıştır. Örneğin, Türklerde devam eden bu oyunlar Osmanlı Dönemi'nde de katı kurallar getirilerek sınırlanmış ve çoğu zaman yasaklanmıştır (And, 1962, 281). Oyunların 'İslami ritüellere uymadığı' inancına, 'orijinleri pagan uzantılıdır' önermeleri de eklenince, bunların bizim öz geleneklerimiz olduğuna dair keskin söz söyleyebilme olanaklarımız bir yana, nesli tükenen bir canlı gibi göz göre göre son soluklarını vermelerine de sebebiyet verilmektedir.

Sonuç olarak; Anadolu'da ve Balkanlarda oynanan bu tarz oyunlarda kullanılan figür ve eylemlerin köklerini, mitolojide ve antikçağ Dionysos Şenlikleri'nde aramayı uygun gören genel kanıya rağmen, ele aldığımız Pıngıdık oyununun seyrinde asli ögeler olarak karşımıza çıkan 'animistik tasarım, dayanışma ve baskın erginlenme' öğelerini Türk geleneği içinde göre- 
bilmeliyiz. İçerikte, ritüelin indirgenebileceği çok sayıda mitolojik ucun vurgulanması, kendi içinde bir tartışma ve mukayese amacı için yapılmıştır. Aslının Orta Asya Türk Geleneği olduğunu kanıtladığımızı düşündüğümüz, Gökbük Köyü Tahtacıları tarafindan oynanan Pıngıdık Oyunu, kökende benzerleri gibi Ön Türklerden başlayarak Orta Asya'dan Anadolu'ya taşınmış ve kısmen orijininden farklı biçimlerde bugüne kadar yaşatılmıştır. Bu oyun farklı uygarlıklardan taklit edilmiş, sonradan öğrenilmiş veya tasarımlanmış değildir.

Birbirleri ile bağ kurmamış uzak toplumlarda dahi ortak mitler ve olguların oluşturulmasının zekânın seyri gereği olduğu (Fiske, 2006, 163), totemik ve animistik tasarımların, birbirlerine benzer nitelikte oyunların, şenlikler ve erginlenme ritüellerinin gelişebileceği gerçeği, Pıngıd1ğın özgün bir ‘Türk Erginlenme Ritüeli’ olduğunu söylememizi gerektirmektedir. 


\section{KAYNAKÇA}

And, M. (1962). Bizans Tiyatrosu. Ankara: Forum Yayınları.

And, M. (1974). Oyun ve Büyü. İstanbul: Türkiye İş Bankası Yayınları.

Artun, E. (1983). Tekirdağ Folklorundan Örnekler. Tekirdağ: Taner Matbaası.

Cömert, B. (1999). Mitoloji ve İkonografi. Ankara: Ayraç Yayınevi.

Crow, W. B. (2002). Büyünün Cadılığın ve Okültizmin Tarihi. Çev.: Fulya Yavuz. İstanbul: Dharma Yayinları.

Çoruhlu, Y. (2010). Türk Mitolojisinin Ana Hatları. İstanbul: Kabalcı Yayınevi.

Dökü, F. E. (2000). Anadolu'da Eril Bereket, Koruyucu Kültler ve Tanrllar. Akdeniz Üniversitesi, Sosyal Bilimler Enstitüsü, Arkeoloji ABD. Yüksek Lisans Tezi, Antalya.

Duymaz, A. (2000). “Dede Korkut Kitabında Alpların Eğitim ve Geçiş Törenleri”. 21. Ekim 1999-Uluslararası Dede Korkut Bilgi Şöleni (Bildiriler). Ankara: Atatürk Kültür Merkezi Başkanlığı Yayınları.

Düzgün, D. (1994). Erzurum Köy Seyirlik Oyunları. Atatürk Üniversitesi, Sosyal Bilimler Enstitüsü, Türk Dili ve Edebiyatı ABD. Yayınlanmamış Doktora Tezi, Erzurum.

Eliade, M. (1991). Kutsal ve Dindışı, Çev: M. Ali Kılıçbay. Ankara: Gece Yayınları.

Eliade, M. (2003). Dinsel İnançlar ve Düşünceler Tarihi. İstanbul: Kabalcı Yayınları.

Erhat, A. (2003). Mitoloji Sözlüğ̈̈. İstanbul: Remzi Kitabevi.

Fiske, J. (2006). Mitler ve Mitleri Yapanlar. İzmir: İlya Yayınları.

Frazer, J. G. (1992). Altın Dal (Dinin ve Folklorun Kökleri). İstanbul: II. Payel Yayınları.

Freud, S. (2002). Totem ve Tabu. Çev: K. Sahir Sel. 3. Basım. İstanbul: Sosyal Yayınlar.

Gülensoy, T. (2011). Türkçe Sözcüklerin Köken Bilgisi. I. Cilt, Ankara: TDK Yayınları.

Karça, Ramazan (1954) Karaçay Malkar Türklerinde Hayvancılık ve Bununla İlgili Gelenekler. Ankara Üniversitesi, Dil ve Tarih Coğrafya Fakültesi Yayını, No: 101. Ankara: Türk Tarih Kurumu Basımevi.

Peterich, E. (1946). Küçük Yunan Mitologyası. Çev.: Suat Y. Baydur. İstanbul: MEB Basımevi.

Özdemir, N. (2000). Dünya Tiyatrosu Tarihi 1. İstanbul: Mitos Boyut Yayınevi.

Özhan, M. (1997). Türkiye'deki Dramatik Köy Seyirlik Oyunlarl Üzerine Bir Atlas Denemesi, 5. Milletler Arası Türk Halk Kültürü Kongresi. Ankara: Kültür Bakanlığı Yayınları No:1872, 292-314.

Somuncuoğlu, S. (2008). Sibirya'dan Anadolu’ya Taştaki Türkler. İstanbul: Güngör Matbaa.

Tavkul, U. (2012). Kafkasların Kalbine Yolculuk/Karaçay Malkar. Ankara:Türksoy Bengü Yayınları.

Thomson, G. (1990). Aiskhylos ve Atina. Çev.: Mehmet Doğan. İstanbul: Payel Yayınevi.

Thomson, G. (1998). Insanın Özü. Çev.: Celal ÜSTER. 5. Basım. İstanbul: Payel Yayınları.

Tokdemir, H. (1993). Artvin Yöresi Folkloru. Ankara: Yayınevi.

Tuna, E. (2000). Şamanlık ve Oyunculuk. İstanbul: Okyanus Yayınları.

Wilkinson, P. (2011). Kökenleri ve Anlamlarlyla Efsaneler ve Mitler. İstanbul: Alfa Yayınları.

\section{Resimler}

1-2-3-4-5-6-7-8-9-10-11-12: Kenan ÇELİKKOL Arşivi.

13: Servet SOMUNCUOĞLU, Sibirya'dan Anadolu'ya Taştaki Türkler, Güngör Matbaa, İst. 2008, 57. 14: Okay SÜTÇÜOĞLU Arşivi. 